\title{
Asthma in Children at the Pediatric Intensive Care Unit of University Hospital of Brazzaville (Congo)
}

\author{
Engoba Moyen ${ }^{1,2 *}$, Esthel Lee Presley Bemba ${ }^{1,3}$, Judicael Kambourou1,2, \\ Gaston Ekouya-Bowassa1,4, Evrard Romaric Nika², Grace Nkounkou'2, Verlem Bomelefa-Bomel2, \\ Annie Rachelle Okoko ${ }^{1,2}$, Georges Moyen ${ }^{1,2}$, Jean-Louis Nkoua1
}

${ }^{1}$ Faculty of Health Sciences, Marien Ngouabi University of Brazzaville, Brazzaville, Congo

${ }^{2}$ Pediatric Intensive Cares Unit, University Hospital of Brazzaville, Brazzaville, Congo

${ }^{3}$ Department of Pneumology, University Hospital of Brazzaville, Brazzaville, Congo

${ }^{4}$ Department of Neonatology, University Hospital of Brazzaville, Brazzaville, Congo

Email: *engoba_m@yahoo.fr

How to cite this paper: Moyen, E., Bemba, E.L.P., Kambourou, J., Ekouya-Bowassa, G., Nika, E.R., Nkounkou, G., Bomelefa-Bomel, V., Okoko, A.R., Moyen, G. and Nkoua, J.-L. (2017) Asthma in Children at the Pediatric Intensive Care Unit of University Hospital of Brazzaville (Congo). Open Journal of Pediatrics, 7, 140-148.

https://doi.org/10.4236/ojped.2017.73017

Received: June 2, 2017

Accepted: August 1, 2017

Published: August 4, 2017

Copyright ( 2017 by authors and Scientific Research Publishing Inc. This work is licensed under the Creative Commons Attribution International License (CC BY 4.0).

http://creativecommons.org/licenses/by/4.0/ (c) (i) Open Access

\begin{abstract}
Objectives: To describe the epidemiological, clinical and therapeutic aspects of asthma in children at the Pediatric Intensive Care Unit of University Hospital of Brazzaville. Patients and methods: We reviewed the records of children hospitalized in the Pediatric Intensive Care Unit of University Hospital of Brazzaville from January 1 to December 31, 2015, and retained those from two months to 17 years hospitalized for asthma. The study variables were: age, sex, influence of seasons, history of atopy; the factors triggering the crisis, the type of follow-up, the degree of severity of asthma exacerbation, the type of treatment instituted and the course of the disease. In total, out of 2012 hospitalized children, 65 children met the inclusion criteria. Results: The hospital prevalence of asthma was $3.5 \%$. Among 65 children of study, 42 (59.2\%) were male and $29(40.8 \%)$ female. The mean age was $3.9 \pm 2.9$ years (range from 2 months to 14 years). Children aged 30 months to 5 years were the most represented (40\%). They were known as asthmatics, $n=18$ (27.7\%). Family atopy was found, $n=11(16.9 \%)$. Acute Otorhinolaryngologic infections were in all cases the factors triggering the crisis. The peak frequency of hospitalizations for asthma occurred during the short rainy season. The crisis was moderate $n=46(70 \%)$ and severe $n=19$ (29\%). Beta 2 mimetics were administered in all cases, by subcutaneous in 18 cases $(27.7 \%)$ and inhaled in 47 cases (72.3\%). The outcome was favorable in all cases with a mean hospital stay of $1.46 \pm 0.92$ days. Conclusion: Childhood asthma remains a public health challenge and severe asthma is the paradigm of uncontrolled and costly asth-
\end{abstract}


ma. This first work suggests that a large-scale study be carried out for a better knowledge of it.

\section{Keywords}

Asthma, Children, Pediatric Intensive Care, CHU, Brazzaville

\section{Introduction}

Asthma is the most common chronic respiratory disease in children [1]. This is a public health problem. It concerns about 235 million people worldwide [1] [2]. In France, its frequency is 10\% [3], in Burkina Faso, $0.5 \%$ in pediatric hospitals [4]. In Congo, the hospital based frequency of asthma in adult patients service was $10.22 \%$ [5]. On the other hand, the pediatric frequency is not known. We have therefore undertaken this study with the aim of reporting the epidemiological, clinical and therapeutic aspects of asthma children at the Pediatric Intensive Care Unit of University Hospital of Brazzaville (Congo).

\section{Patients and Methods}

We carried out a retrospective and descriptive study in the pediatric intensive care unit of the University Hospital of Brazzaville, covering the period from January $1^{\text {st }}$ to December $31^{\text {st }}$, 2015. We reviewed all medical records of children aged from 2 Months to 17 years, hospitalized during the study period and included those whose exit diagnosis included the asthma item. The diagnosis of Asthma was retained in children over three years of age presenting cough episodes with or without sputum, wheezing, expiratory dyspnea, wheezes, and a reversibility of signs spontaneously or due to the effect of bronchodilators.

In children under three years of age, this diagnosis was retained when they had at least two previous episodes of bronchiolitis. Children who had obstructive upper airway malformation and/or other chronic diseases such as kidney failure, heart disease, or malnutrition, were excluded.

The variables studied were age, gender, influence of seasons, existence of a history of atopy and asthma, factors triggering the asthma attack, type of follow-up, pre-hospital background therapy, existence of prodromes, degree of severity of asthma exacerbation, radiological imaging, established treatment, progression and duration of hospitalization. The exacerbation of asthma was defined by the persistence of the crisis beyond 24 hours. As before, this exacerbation was classified as a mild, moderate and severe crisis [6] [7].

\subsection{Patients}

During the study period, 2012 children were hospitalized in the service. Of these, 71 (3.5\%) children as an exacerbated asthma attack, among which were 42/1089 (3.8\%) of male and $29 / 923(1.2 \%)$ of female. For this work, only 65 cases involv- 
ing 42 male (59.2\%) and 29 female (40.8\%) were selected.

\subsection{Statistical Analysis}

The data were entered and analyzed using the Epi Info 3.5.3 software. The statistical tests used were the chi-square and the Students $t$-test. For all tests, the significance level was set at $5 \%$.

\section{Results}

\subsection{Sociodemographic Parameters}

The 65 children selected for this study were aged of $3.9 \pm 2.9$ years (range: two months and 14 years). In 30 (46.1\%) cases, they were under 30 months of age; in $18(27.7 \%)$ cases, between 31 and 71 months; and in 15 (23.1\%), cases between 6 and 10 years. Only two children, $3.1 \%$ aged 11 and 12 years. They were 42 (59.2\%) male and 29 (40.8\%) female, a sex ratio of 1.45 .

Compared to the general population of the service, the frequency was 3.9 for 1089 male and 3.1 for 923 female, a sex ratio of 1.18.

\subsection{Influence of Seasons}

Admissions for asthma occurred in $36(55.38 \%)$ cases between March and June, while in other months, only an average of four children were admitted per month (Figure 1).

\subsection{Antecedents}

All 65 children were born at term. They had a history of bronchiolitis in 25 (38.5\%) cases. They were known to have asthma in 18 (27.7\%) cases, 8 (12.5\%) of which were followed by a pediatrician. In follow up children, treatment consisted to the administration of beta 2 mimetics in spray as a background treat-

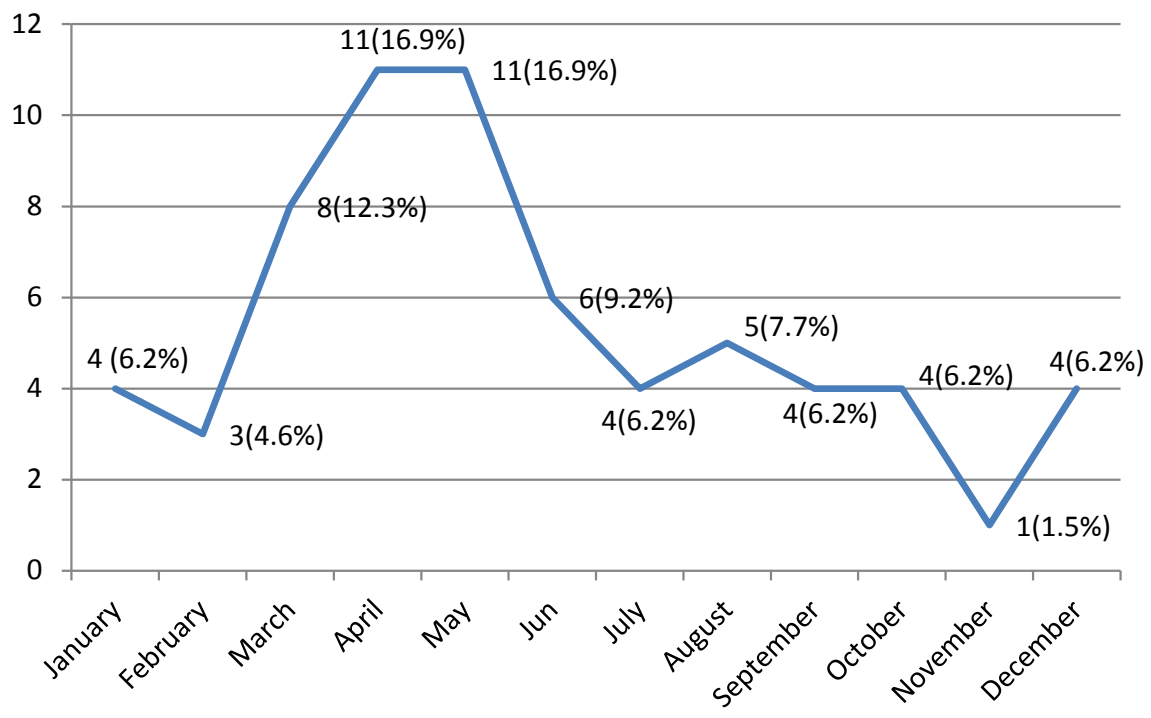

Figure 1. Distribution of patients by month of hospitalization. 
ment. These patients were aged $5.4 \pm 3.5$ years versus $3.2 \pm 2.9$ years for those who did not know asthma $(p=0.006)$. The history of familial atopy was found in $11(16.9 \%)$ children, in all cases it was a history of asthma. No case of passive smoking was found.

\subsection{Circumstances of Hospitalization}

The triggers of the asthma attack were an otorhinolaryngologic infection in all cases.

Patients came directly from home $(n=50 ; 79.4 \%)$ or referred by a secondary health center $(n=15 ; 20.6 \%)$. The mean time between onset of symptoms and consultation was $2.28 \pm 1.72$ days with extremes of 12 hours to 7 days. Dyspnea was the main reason for hospitalization in all cases.

\subsection{Clinical Aspects}

The functional and general signs are given in Table 1.

Signs of pulmonary auscultation, some associated in the same patient, were observed in the following proportions: wheezes alone 58 cases $(89.2 \%)$, wheezes associated with ronchi 5 cases $(7.7 \%)$, and with crackles 17 cases $(26.1 \%)$. Seizures were considered moderate in $46(70.8 \%)$ patients and severe in 19 (29.2\%) patients.

\subsection{Radiographic Aspects}

The chest X-ray, performed in 45 patients (69.2\%), was normal in 25 cases (55.6\%), showed thoracic distension in 18 cases (40.0\%), atelectasis and alveolar image in one case each (2.2\%).

\subsection{Treatment}

The treatment consisted in all cases of administration of beta 2 mimetics, subcutaneously $(n=5 ; 7.7 \%)$ or inhaled $(n=60 ; 92.3 \%)$ by spray $(n=39 ; 60 \%)$ or in nebulization $(n=21 ; 32.30 \%)$. In combination with oxygen therapy in all cases, corticosteroids were administered in $52(80.0 \%)$ cases, as slow intravenous methylprednisolone to 50 children (76.9\%), and betametasone per os 2 (3.1\%). Antibiotic therapy was administered in $16(24.6 \%)$ cases. It was a beta-lactam in 5

Table 1. Functional and general signs.

\begin{tabular}{ccc}
\hline & $\mathrm{N}$ & $(\%)$ \\
\hline Asthenia & 15 & 4.0 \\
Fever & 43 & 66.1 \\
Cough & 53 & 81.5 \\
Rhinorrhea & 44 & 67.6 \\
Expectoration & 7 & 10.7 \\
Sneeze & 2 & 3.0 \\
Difficulties feeding & 17 & 26.1 \\
\hline
\end{tabular}


(31.0\%) cases, a macrolide in $1(6.0 \%)$ case, and a combination of beta-lactam and macrolide in $10(63.0 \%)$ cases. There was no significant difference between the type of antibiotic prescribed and the age groups $(p=0.64)$.

\subsection{Evolution}

The outcome was favorable in all cases. The mean hospital stay was $1.46 \pm 0.92$ days (range $=12$ hours -6 days). For severe seizures, and $1.7 \pm 1.4$ days (range 1 6 days) for seizures: significant difference $(p=0.04)$.

\section{Discussion}

\subsection{Analysis of Methods}

Asthma occurs in various forms: mild or intermittent asthma, moderate, and severe [8]. Some recommendations [9] classified the severity of asthma in terms of symptom intensity, level of obstruction, and variability in respiratory function in four categories: intermittent, moderate persistent, and severe. The intermittent forms, the most numerous, are followed in outpatient medicine. However, mild to moderate persistent types can be managed in general pediatric hospitalization. On the other hand, exacerbations of life-threatening asthma attacks should be treated in intensive care units. This means that the hospital frequency reported in this work (3.5\% of intensive care hospitalizations) has a recruitment bias. In terms of diagnosis, only $67.7 \%$ of asthmatic children admitted to the pediatric intensive care unit had a chest radiograph. The realization of this examination, simple and inexpensive, should be systematic in the management [10]. In addition, none of our patients have received spirometry: this is a key diagnostic examination [1], whose contribution to follow-up is important [11].

\subsection{Frequency}

In a hospital and pediatric population, frequencies of $0.51 \%$ have been reported in Ouagadougou [4], $1 \%$ in Lomé [12], and 2\% in Dakar [13]. In a hospital clinic for adults and children in Dakar [14], the frequency of asthma was $7.5 \%$. In Congo, a hospital survey [5] assessed the frequency of asthma but recruited mainly adults. However, through the use of a simple and validated questionnaire, one survey [15] reported that $19.9 \%$ of Congolese aged 13 - 14 years had asthma. In France, three national surveys carried out in children [3] reported frequencies from $12.3 \%$ to $13.4 \%$.

The mean age of onset reported in our work (3.5 years) is comparable to the French [16] and Malaysian [17] ones, with respectively $3.9 \pm 3.3$ years and $3 \pm$ 2.5 years. Other African authors [4] [12] reported higher mean ages of 6.5 and 7 years, respectively. This difference could be explained by the size of our sample.

\subsection{Circumstances of Occurrence}

Our study covered only 12 months. It reported a higher frequency of admissions from March to June, a period corresponding to the small rainy season, whereas 
this recrudescence was observed during the Great dry seasons in Togo [18]. In both cases, these are the seasons whose common denominator is the existence of dust. This is, with cold and respiratory infections [4] [5] [11] [18] [19] as a factor triggering asthma attacks. Indeed, asthma is a complex disease with multifactorial etiology, with atopy being the most frequently identified risk factor [4] [11] [16]. In children, 95\% of cases originate from the hereditary allergic field, compared with $70 \%-80 \%$ in adults [11]. The exact cause of asthma remains unknown, but might be the result of a complex interaction between environmental factors and various individual or genetic factors (predisposition or family history). Thus, according to Burrows et al. [20], the risk to the child of developing an allergic disease is all the greater as the number of individuals affected in the family is high.

\subsection{Clinical and Para-Clinical Aspects}

The clinical expression of asthma attacks included, in our work, the usual signs reported elsewhere [3]; The majority of which were cough in $81.5 \%$, rhinorrhea (67.6\%), and wheezes (89.2\%). This clinical expression and the evolution with regard to the therapeutic means implemented suggest that we have recruited many cases of severe acute asthma. However, some signs such as the fever observed in 43 patients $(66.1 \%)$, the radiological images of atelectasis, and the use of antibiotic therapy in $n=16(24.6 \%)$ cases make it possible to discuss the possibility of bacterial pneumonia in children under five years of age [21].

\subsection{Therapeutic Aspects and Evolution}

We used $\beta$-mimetics in 39 children (60\%), as in the Burkinabe study of OUADRAOGO et al. [4] (60\%), and $82.8 \%$ for THIAM et al. [14]. It is now admitted [6] [22] [23], on the one hand that short-acting $\beta$-mimetics are first-line treatment irrespective of the age of the child or the level of severity of the crisis, and on the other that their preferred way of administration is the inhaled route. In line with current practice recommendations, we used this approach in 60 (92.3\%). Children, the administration of corticosteroids was frequent in our experience: 52 cases, i.e. $80.0 \%$. This was consistent with the degree of severity in that we used the parenteral way in $96.1 \%$. Indeed, corticosteroids are indicated by oral inhalation [24] in the crisis and exacerbation of asthma. Having not demonstrated superiority to the oral way, the parenteral way should be reserved for children unable to ingest treatment or because of vomiting [22]. Glucocorticoid therapy should be administered in short cures because of the effects on growth. Indeed, the use of short courses of corticosteroids during seizures was recently re-evaluated [25] by three tests: measurement of markers of bone turnover, ACTH test, and bone densitometry. These tests are not significantly altered in children receiving an average of five courses a year.

The daily administration of inhaled corticosteroids, in combination with longacting $\beta$-mimetics if necessary, is the background treatment of childhood asthma 
to prevent exacerbations and achieve daily symptom control [26]. In monotherapy, it has been shown to be superior to other treatments such as anti-leukotrienes [27]. None of our patients used a background treatment, although eight of them were monitored. In this retrospective study, we were not able to classify the asthmatic disease according to the type of evolution.

\section{Conclusion}

The importance and frequency of asthma in the Pediatric Intensive Care Unit in Brazzaville require that preventive measures be implemented. These go through the education of patients and parents of the asthmatic child, the use of written instructions that proved beneficial, and compliance with the coding of its care.

\section{References}

[1] Masoli, M., Fabian, D., Holt, S., Beasley, R., et al. (2004) The Global Burden of Asthma: Executive Summary of the GINA Dissemination Committee Report. Allergy, 59, 469-478. https://doi.org/10.1111/j.1398-9995.2004.00526.x

[2] Wold Health Organization. Asthma. Available from: http://www.who.int/mediacentre/factsheets/fs307/en/

[3] Delmas, M.C., Guignon, N., Leynaert, B., Com-Ruelle, L., Annesi-Maesano, I., Herbet, J.B. and Fuhrman, C. (2009) Prévalence de L'asthme chez L'enfant en France. Archives de Pédiatrie, 16, 1261-1269. https://doi.org/10.1016/j.arcped.2009.06.009

[4] Ouedraogo, S.D., Koueta, F., Ramde, J., Sawadogo, H., Kabore, S., Dao, L., Kam, L. and Ye, D. (2015) Profil Epidémiologique, Clinique et Thérapeutique de L'Asthme en Milieu Hospitalier Pédiatrique au sud du Sahara. Medecine d'Afrique Noire, 62, 101-111.

[5] Presley, B.E.L., Judicael, K., Engoba, M., Okombi-Okemba, F.H., Ouedraogo, A.R., Ossalé, A.K.B., Bopaka, R.G., Nkanga, A. and Mboussa, J. (2014) Asthme Bronchique de L'Adulte au Service de Pneumologie du CHU de Brazzaville. Revue de Pneumologie Tropicale, 22, 3-10.

[6] Denlinger, L.C., Sorkness, C.A., Chinchilli, V.M. and Lemanske Jr., R.F. (2007) Guideline-Defining Asthma Clinical Trials of the National Heart, Lung, and Blood Institute's Asthma Clinical Research Network and Childhood Asthma Research and Education Network. Journal of Allergy and Clinical Immunology, 119, 3-11. https://doi.org/10.1016/j.jaci.2006.10.015

[7] Marguet, C. (2007) Prise en Charge de la Crise D'asthme de L'enfant (Nourrisson inclus). Recommandations Pour la Pratique Clinique. Revue Des Maladies Respiratoires, 24, 427-439. https://doi.org/10.1016/S0761-8425(07)91567-3

[8] Sheffer, A.L. (1992) International Consensus Report on the Diagnosis and Management of Asthma. Asthma Management Project. Clinical \& Experimental Allergy, 22, S1-S71.

[9] Asthma. Global Srategy for Asthma Management and Prevention. Revised 2014 Vancouver, GINA 2014. Available from: http://ginasthma.org/

[10] Ducou, L., Pointe, H. and Montagne, J.P. (1999) Radiologie de L'asthme. Médecine Thérapiel Pédiatrie, 2, 180-184.

[11] Anonyme (2007) L'asthme. Journal de Pédiatrie et de Puériculture, 20, 84-90. 
https://doi.org/10.1016/j.jpp.2007.02.002

[12] Tanoh, A., Hayathe, A., Ngoan, M. and Lasme, E. (1998) Profil et Prise en Charge de la Crise D'asthme en Milieu Hospitalier Pédiatrique à Abidjan (Côte d'Ivoire). Medecine d'Afrique Noire, 45, 304-307.

[13] Ba, M., Camara, B., Ndiaye, O., Diouf, S. and Ba, A. (2002) Asthme des Enfants au Sénégal: Caractéristiques Epidémiologiques et Cliniques dans les Hôpitaux. Dakar Médical, 47, 128-133.

[14] Thiam, K., Ndiaye, E.H.M., Kane, Y., et al. (2013) Profil Epidémiologique, Clinique et Thérapeutique de L'asthme dans une Consultation de Pneumologie au Centre Hospitalier National Universitaire (CHNU) de Fann. Dakar. Medecine d'Afrique Noire, 60, 496-502.

[15] Ait-Khaled, N., Odhiambo, J., Pearce, N., Adjoh, K.S., Maesano, I.A., Benhabyles, B., et al. (2007) Prevalence of Symptoms of Asthma, Rhinitis and Eczema in 13 to 14-Year-Old Children in Africa: The International Study of Asthma and Allergies in Childhood Phase III. Allergy, 62, 247-258.

https://doi.org/10.1111/j.1398-9995.2007.01325.x

[16] Julian, V., Pereira, B. and Labbé, A. (2014) Caractéristiques des Consultations Pour Exacerbation D'asthme aux Urgences Pédiatriques. Evaluation et Perspectives Pour une Amélioration de la Gestion Pré-Hospitalière. Revue Des Maladies Respiratoires, 31, 13-20. https://doi.org/10.1016/j.rmr.2013.04.021

[17] Azizi, B.H.O., Zulkini, H.I. and Kassim, S. (1995) Indoor Pollution and Asthma in the Hospitalised Children in a Tropical Environnement. Journal of Asthma, 32, 413-418. https://doi.org/10.3109/02770909409077752

[18] Tidjani, O., Silue, Y., Gbadoe, A. and Kassankogno, Y. (1994) Aspect Epidémiologique de L'asthme en Milieu Scolaire dans la Commune de Lomé (Togo). Medecine d'Afrique Noire, 41, 331-335.

[19] Moussaoui, R. and Kettani, E. (2004) Les Asthmes Aigues Graves en Réanimation Pédiatrique. Journal Maghr d'anesthésie Réanimation et de médecine d'urgence, 11, 22-25.

[20] Burrows, B., Martinez, F.D., Cline, M.G., et al. (1995) The Relationship between Parental and Children's Serum IgE and Asthma. American Journal of Respiratory and Critical Care Medicine, 152, 1497-1500.

https://doi.org/10.1164/ajrccm.152.5.7582283

[21] Østergaard, M.S., Nantanda, R., Tumwine, J.K. and Aabenhus, R. (2012) Childhood Asthma in Low Income Countries: An Invisible Killer? Primary Care Respiratory Journal, 21, 214-219. https://doi.org/10.4104/pcrj.2012.00038

[22] National Asthma Education and Prevention Program (2002) Expert Panel Report: Guidelines for the Diagnosis and Management of Asthma Update on Selected Topics-2002. Journal of Allergy and Clinical Immunology, 110, 141-219.

[23] Hossny, E., Rosario, N., Lee, B.W., Singh, M., El-Ghoneimy, D., Soh, J.Y. and Le Souef, P. (2016) The Use of Inhaled Corticosteroids in Pediatric Asthma: Update. World Allergy Organization Journal, 12, 9-26. https://doi.org/10.1186/s40413-016-0117-0

[24] Siret, D., Luc, C. And Dubus, J.C. (2005) La Nébulisation dans L'asthme de l'enfant. Archives de Pédiatrie, 12, S139-S141. https://doi.org/10.1016/S0929-693X(05)80031-4

[25] Ducharme, F.M., Chabot, G., Polychronakos, C., Glorieux, F., Mazer, B. (2003) Safety Profile of Frequent Short Courses of Oral Glucocorticoids in Acute Pediatric Asthma: Impact on Bone Metabolism, Bone Density, and Adrenal Function. 
Pediatrics, 111, 376-383. https://doi.org/10.1542/peds.111.2.376

[26] Carsin, A., Baravalle, M. and Dubus, J.-C. (2016) Actualités de la Corticothérapie Inhalée dans le Traitement de l'asthme chez l'enfant: Traitement Continu ou à la Demande. Revue Française d'Allergologie, 56, 124-125.

https://doi.org/10.1016/j.reval.2016.02.001

[27] Chauhan, B.F. and Ducharme, F.M. (2012) Anti-Leukotriene Agents Compared to Inhaled Corticosteroids in the Management of Recurrent and/or Chronic Asthma in Adults and Children. The Cochrane Database of Systematic Reviews, 5, Article ID: CD002314. https://doi.org/10.1002/14651858.CD002314.pub3

Submit or recommend next manuscript to SCIRP and we will provide best service for you:

Accepting pre-submission inquiries through Email, Facebook, LinkedIn, Twitter, etc. A wide selection of journals (inclusive of 9 subjects, more than 200 journals)

Providing 24-hour high-quality service

User-friendly online submission system

Fair and swift peer-review system

Efficient typesetting and proofreading procedure

Display of the result of downloads and visits, as well as the number of cited articles

Maximum dissemination of your research work

Submit your manuscript at: http://papersubmission.scirp.org/

Or contact ojped@scirp.org 